\title{
АНАЛИЗ СОВРЕМЕННОГО СОСТОЯНИЯ МЕТОДА ОДНОВРЕМЕННОЙ РАЗДЕЛЬНОЙ ЭКСПЛУАТАЦИИ СКВАЖИН
}

\author{
Деряев Аннагулы Реджепович \\ кандидат технических наук \\ научный сотрудник
}

Научно-исследовательский институт природного газа ГК «Туркменгаз»

\begin{abstract}
Аннотация: Одной из важнейших задач для успешного ведения буровых работ на площадях с многопластовыми продуктивными горизонтами является обоснованный правильный выбор и разработка конструкции для одновременнораздельной эксплуатации скважин.
\end{abstract}

Ключевые слова: гидродинамическая связь, сетка скважин, нагнетательная скважина, электроцентробежный насос, штанговый глубинный насос, двухлифтная эксплуатация.

В данное время на многопластовых месторождениях по традиционной схеме эксплуатации месторождений предусматривается разработка сетки вертикальных скважин для каждого эксплуатационного объекта, что приводит к увеличению капитальных затрат на бурение скважин и снижению рентабельности получаемой продукции. Соответственно, при добыче углеводородного сырья основной статьей затрат является строительство новых эксплуатационных скважин. Решать проблему снижения затрат на строительство приходится практически сразу с вводом скважин в бурение. Наиболее простым способом является объединение нескольких нефтенасыщенных горизонтов в несколько объектов разработки.

На многопластовых нефтяных месторождениях с многослойными нефтяными пластами применение многопластовых вертикальных и наклонных скважин может быть значительно эффективнее применения однопластовых горизонтальных скважин:

- во-первых, эффективнее по дебиту нефти (увеличение дебита нефти в 3 - 4 раза вместо увеличения в 2 - 3 раза); 
- во-вторых, по простоте контроля и управления эксплуатацией пластов;

- в-третьих, по возможности изоляции отдельных обводненных пластов [1].

При разработке многопластовых нефтяных месторождений важное значение имеют вопросы изучения гидродинамической связи между добывающими и нагнетательными скважинами не только в целом по продуктивному горизонту, но и по каждому пласту для принятия своевременных мер по регулированию их разработки.

Для разработки многопластовых нефтяных месторождений одной сеткой скважин необходимо разделить продуктивную свиту на эксплуатационные объекты. Под эксплуатационным объектом обычно понимают один или несколько пластов, которые эксплуатируются скважиной совместно. Правильное выделение эксплуатационных объектов и последующая их совместная эксплуатация повышают технико-экономические показатели разработки: уменьшают капиталовложения, повышают производительность скважин, сокращают сроки разработки месторождения.

Проектирование разработки многопластовых нефтяных месторождений ведется с обязательным учетом применения одновременной раздельной эксплуатации.

При разработке многопластовых нефтяных месторождений в скважину спускают две и даже три параллельные эксплуатационные колонны для раздельной эксплуатации разных объектов. В этом случае диаметр каждой эксплуатационной колонны выбирают индивидуально с учетом названных выше факторов. Глубина спуска каждой колонны, как правило, определяется глубиной залегания соответствующего продуктивного объекта. В некоторых зарубежных фирмах иногда все эксплуатационные колонны спускают до проектной глубины скважины; при этом улучшаются условия цементирования скважины, но стоимость ее возрастает.

Продуктивные горизонты многопластового нефтяного месторождения, как правило, различаются по фильтрационным и коллекторским характеристикам. Эти характеристики могут в значительной мере изменяться как по мощности, так и по простиранию [2].

Однако на многопластовых нефтяных месторождениях, имеющих 3, 4 или 5 малопродуктивных нефтяных пластов, возможно одно из самых действенных средств увеличения дебитов нефти - объединение пластов в один 
общий эксплуатационный объект с одной общей сеткой добывающих и нагнетательных скважин. Понятно, что это сразу уменьшает капитальные затраты на строительство и обустройство скважин в 3, 4 или 5 раз.

Известны способы разработки многопластовых нефтяных месторождений:

- единой сеткой добывающих и нагнетательных скважин, без выделения двух и более эксплуатационных объектов. Но этот способ в большинстве случаев малоэффективен.

- способ, при котором каждый нефтяной пласт разрабатывается отдельно своей собственной самостоятельной сеткой добывающих и нагнетательных скважин.

- способ, по которому каждый обособленный нефтяной пласт разрабатывается своей сеткой добывающих и нагнетательных скважин Основной недостаток этого способа состоит в многократном увеличении капитальных и текущих экономических затрат на добычу нефти. А в случаях, когда нефтяные пласты оказываются заниженной и низкой продуктивности, применение этого способа приводит к экономической нерентабельности и фактической невозможности разработки таких нефтяных месторождений.

- способ, при котором каждый нефтяной пласт разрабатывается отдельно своей собственной самостоятельной сеткой добывающих и нагнетательных скважин. При этом получается, что на нефтяной площади, где несколько нефтяных пластов, столько же самостоятельных сеток скважин, во столько же раз увеличено общее число скважин и соответственно увеличены общие капитальные затраты. Недостатком этого способа может быть чрезмерное увеличение общего числа скважин и капитальных затрат.

- способ с выделением двух и более эксплуатационных объектов и применением по каждому объекту совершенно самостоятельной сетки скважин со своей плотностью. Причем сетки берут ближайшие по плотности из рекомендованного набора сеток: 600х600 м или 36 га скважину.

Регулирование процесса разработки многопластовых нефтяных месторождений проводится также путем изменения режима закачки по пластам, с применением оборудования для одновременно-раздельного нагнетания в несколько пластов через одну скважину.

Проектирование разработки и доразработки многопластовых нефтяных месторождений ведется с обязательным учетом применения одновременно раздельной эксплуатации нескольких продуктивных горизонтов одной 
скважиной. Это позволяет сокращать число скважин, требуемое для разбуривания месторождений, сроки их разработки и снижать себестоимость добываемой продукции. Поэтому проектировать и бурить наклонно направленные скважины следует с учетом особенностей подземного оборудования для одновременно раздельной эксплуатации нескольких горизонтов одной скважиной. [3].

Практика показала, что успешность и эффективность одновременно раздельной эксплуатации зависит от технического обеспечения и инженерного сопровождения технологии. В части технического обеспечения отечественными разработками накоплен значительный опыт одновременнораздельной эксплуатации нефтяных скважин с использованием газлифтного способа добычи. Сложнее обстоит дело при одновременно-раздельной эксплуатации пластов с использованием установок электроцентробежный насос (ЭЦН) и + штанговый глубинный насос (ШГН). В этом направлении значительные работы проведены в России и ведущими компаниями мира Шлюмберже, Бейкер, Камко. Например, научными подразделениями Сургут НИПИнефть, НИИ «СибГеоТех» г. Нижневартовск.

Разработана техническая документация:

- РД-39-12-016-2003 «Технология одновременно-раздельной эксплуатации нескольких пластов скважиной, эксплуатируемой УЭЦН;

- РД-39-12-017-2003 «Технология одновременно-раздельной эксплуатации нескольких пластов скважиной, эксплуатируемой УШГН.

Технология включает:

- подбор компоновки (комплектация внутрискважинного оборудования);

- инженерное сопровождение по учету и оптимизации отборов жидкости из каждого пласта;

В настоящее время используются следующие системы одновременнораздельной добычи:

1. Однолифтовые системы

- системы мониторинга с одним способом механической добычи без разделения пластов;

- системы мониторинга (и управления) с одним способом мех добычи с разделением пластов;

- системы с разделением пластов с двумя способами мех добычи.

2. Двухлифтовые системы НКТ 
- параллельные конструкции (колонны НКТ расположены параллельно);

- концентрические конструкции (труба в трубе).

Рассмотрим использование современных методов одновременнораздельной эксплуатации - двухлифтовые системы. Их основное преимущество - 100\% независимая добыча из каждого из пластов. К их недостаткам относятся:

- ограничение по диаметру эксплуатационной колонны (168мм);

- ограниченная глубина в варианте с установкой штангово-глубинных насосов (далее УШГН);

- сложность конструкций;

- необходима специализированная квалификация;

- необходимость использования специализированного оборудования, включая превентор.

В настоящее время работы по внедрению систем ОРЭ активно проводятся компаниями “ТНК-ВР”, “Татнефть”, “Башнефть”, “Шлюмбердже”, “Везерфорд”, “Бейкер Хъюз” и другие.

Так, к примеру, пилотные проекты компании “ТНК-ВР” были осуществлены «Сорочинскнефть» на 2 скважинах. Требования к скважине при одновременной раздельной добыче штанговый глубинный насос + штанговый глубинный насос для двухлифтной эксплуатации:

- Минимальные интервенции (одновременно раздельная пластовая закачка, гидроразрыв пласта).

- не более 2 разобщаемых объектов;

- > 10 м. для посадки пакера между пластами,

- требования к раздельному учету,

- небольшой пространственный угол,

- эксплуатационная колонна от 168 мм,

- глубина установки для ШГН до +/- 2500 м;

- состояние колонн и цементного кольца,

- минимум осложняющих факторов добычи,

- потенциал пластов (для рентабельности).

В компании “ТНК ВР" применялось при одновременной раздельной добыче электроцентрабежный насос + электроцентрабежный насос для двухлифтной эксплуатации. 
Преимущества данной системы:

- $100 \%$ независимая добыча из каждого из пластов.

- Спуск колонн последовательно ЭЦН+ЭЦН.

Недостатки:

- Ограничение по диаметру эксплуатационной колонны (178 мм) при стандартных УЭЦН

- Сложность конструкции;

- Сложность ремонта, требующего высококвалифицированного специализированного персонала;

- Большая чувствительность к ГРП и интервенциям;

- Высокая стоимость спуска и ремонта.

Пилотный проект осуществлен подразделениями ТНК-ВР по типу ШГН+ЭЦН - «СНГ» в $2011-4$ скважины, 2012 - 10 скважин. По типу ЭЦН + ЭЦН. «ТНК-Уват» 1 скважина в 2010 г.

Применение технологии одновременной раздельной эксплуатации высоко развита в компании “Татнефть”. Разработанные специалистами ТатНИПИнефть установки для ОРЭ позволяют одновременно эксплуатировать объекты с разными коллекторскими характеристиками и свойствами. Их применение повышает рентабельность отдельных скважин за счет подключения к ним других объектов разработки или разных по продуктивности пластов одного объекта разработки. За счет оптимизации работы объектов повышается производительность скважины. Использование ствола одной скважины и организация одновременного (совместного) отбора запасов углеводородов разных объектов разработки одной сеткой скважин сокращает объемы бурения [4]. Таким образом, технология ОРЭ позволяет значительно оптимизировать затраты на добычу нефти.

В компании используются различные конструкции, среди которых однолифтовая конструкция ОРЭ для штанговых глубинных насосов (ШГН), двухлифтовая ШГН-ШГН с раздельным подъемом добываемой продукции, конструкции ОРЭ ШГН-ЭЦН (с электроцентробежным насосом) с совместным и раздельным подъемами продукции.

В компаниях “Везерфорд”, “Шлюмбердже”, “Бейкер Хьюз” и других компаниях с целью ведение одновременной раздельной добычи двумя параллельными лифтами из многопластовых горизонтов разработаны специальные двухствольные пакеры, которые надежно зарекомендовали себя в промысловых условиях, обладая достаточной гибкостью применения и 
соответствуя требованиям заканчивания скважин с применением нескольких лифтовых колонн. Технология одновременно-раздельной эксплуатации имеет большое количество преимуществ, ключевые из которых - уменьшение сеток бурения и обеспечение оптимальной разработки пластов. С приближением к максимальному разделению добычи, возрастает сложность технологий и их стоимость. Существует большой спектр технологий. При этом универсальной системы одновременно-раздельной эксплуатации на сегодня нет.

Применение систем одновременно-раздельной эксплуатации (далее ОРЭ) способно существенно улучшить экономическую эффективность инвестиций во всех добывающихся компаниях, обеспечить оптимальную выработку пластов и минимизировать технологическое влияние на окружающую среду. К настоящему времени Компанией наработан обширный опыт тестирования технологий ОРЭ, и в ближайшие годы масштаб их применения значительно расширится. В ряду случаев бурение отдельных скважин на каждый объект разработки экономически нецелесообразно. Кроме того, часто для строительства большого количества скважин имеются технические или логистические ограничения. При этом разработка пластов последовательным способом замедляет освоение запасов. Эксплуатация разных объектов одной скважиной с применением технологий ОРЭ способна сократить объемы бурения, обеспечить прирост добычи, ускорить ввод запасов в разработку и снизить вредное воздействие на окружающую среду.

\section{Внедрение двухлифтовых систем.}

К настоящему времени в многими зарубежными компаниями протестирован тип систем одновременная добыча с параллельными лифтами технология “ШГН+ШГН”,“ЭЦН+ЭЦН”,“ШГН+ЭЦН”, “фонтан+фонтан”, “фонтан+газлифт”, “газлифт+газлифт”.

Существенный рост инвестиций в технологии ОРЭ требует систематизации подходов к корпоративному управлению данным процессом. Выбор систем ОРЭ должен быть привязан к конкретным геологическим условиям, удовлетворять критериям надежности и экономической эффективности на всем цикле жизни скважины.

На фоне подскочивших за последние годы цен на нефть ОРЭ пытаются использовать в процессе разработки месторождений большинство отечественных нефтедобывающих предприятий. Рост цен воодушевил даже самых скупых нефтяников, и они принялись "оживлять" нерентабельные месторождения. 
Первая проблема, с которой столкнулись нефтяные компании, это обеспечение скважин информационными технологиями. Цель любого производителя, который решился на установку оборудования ОРЭ, кроме увеличения добычи нефти - наличие подробной информации из каждого пласта, чтобы управлять процессом добычи в онлайн-режиме.

Сегодня большинство измерений во многих месторождениях ведутся "дедовскими" методами: инженер объезжает в течение нескольких дней все скважины и дает усредненные данные. Новые технологии буквально вдохновили нефтяников, и даже самые прижимистые забыли об экономии, настроились на внедрение и ОРЭ, и систем «умная скважина».

В западных зарубежных странах этот вопрос уже давно решили, подключив датчики к спутниковым системам. У нас же на многих месторождениях работает электрорелейная связь, где-то - сотовая, качество которой часто оставляет желать лучшего. Вдобавок, информация не всегда оказывается доступной, особенно на месторождениях с большим количеством скважин.

Поэтому, устанавливая системы ОРЭ, их производители предлагают нефтяным компаниям различные компоновки оборудования для регулировки пластового давления и утилизации добываемой вместе с нефтью воды, используемой также для получения нужного уровня давления.

\section{Список литературы}

1. Костин Ю.С. Современные методы направленного бурения скважин/ Ю.С. Костин- Москва. Недра, 1982г.

2. Зиненко В.П. Направленное бурение: учебное пособие для вузов/ В.П. Зиненко - Москва Недра, 1990 г.

3. Костин Ю.С. Современные методы и технологии по управлению траекториями геологоразведочных скважин/ Ю.С.Костин, Ю.Г. Соловов, В.В. Нескоромных и другие - "Ресурсы Забайкалья", 2004г. Нескоромных В.В, Калинин.А.Г, Направленное бурение. Москва, ЦентрЛитНефтеГаз.

4. Деряев А.Р., Гулатаров Х.Г., Эседулаев Р.Э. Технология бурения направленных наклонных и горизонтальных скважин и расчеты их проектирования / (монография). Ашгабат: наука, 2020. - стр. 608. 